\title{
THE INFLUENCE OF LEADERSHIP BEHAVIOR AND WORK MOTIVATION ON SERVICE QUALITY AT THE POPULATION AND CIVIL REGISTRATION OFFICE OF BOALEMO REGENCY
}

\author{
Adnan Marzuk ${ }^{1)}$, Arifin Tahir ${ }^{2)}$, and Wiliam Indra S. Mooduto ${ }^{3)}$ \\ 1,2,3) Postgraduate Program STIA Bina Taruna Gorontalo \\ E-mail: adnanmarzuk15@gmail.com
}

\begin{abstract}
The purpose of this research is: 1) to find out and explain partially the influence of leadership behavior on the quality of population administration services at the Population and Civil Registration Office of Boalemo Regency; 2) to find out and explain there is a partial influence of employee work motivation on the quality of population administration services at the Population and Civil Registration Office of Boalemo Regency; 3) to find out and explain there is a simultaneous influence between leadership behavior and employee work motivation on the quality of population administration services at the Population and Civil Registration Office of Boalemo Regency.

Quantitative descriptive research method approach with survey research type that explains the caesal relationship and conduct hypothesis testing with multiple regression analysis approach.

The results showed that: 1) There is a positive and significant influence between leadership behavior on service quality at the Population and Civil Registration Office of Boalemo Regency, which means that the better the behavior of a leader, the better the quality of service; 2) There is a positive and significant influence between work motivation on service quality at the Population and Civil Registration Office of Boalemo Regency, which means that the increase in employee motivation, the better the service provided; 3) There is a positive and significant influence between leadership behavior and work motivation on the quality of service at the Population and Civil Registration Office of Boalemo Regency, which means that the increase in employee work motivation, the better the service provided.
\end{abstract}

keyword: leadership behavior, work motivation, service quality

\section{INTRODUCTION}

Public services are all activities to fulfill basic needs appropriate to the basic rights of every citizen or resident of goods, services and administrative services provided by service providers related to the public interest. Service quality is a condition in which a dynamic relationship is created between users and service providers, both services and humans. Public services are closely related to capability, responsiveness, timeliness, and available infrastructure. If the services provided are appropriate with what is expected by service users, it can be said that the service is a quality service. Conversely, if the services provided are not appropriate with the expectations of service users, it can be said that the services are not of high quality. Good or bad service quality is not based on the point of view or perception of the service provider but based on consumer perceptions and rules or regulations regarding service quality. Public services provided by government agencies have not been able to meet the quality expected by the

Submit: Oct. $16^{\text {th }}, 2020$

Accepted: Dec. $5^{\text {th }}, 2020$

Published: Dec. $17^{\text {th }}, 2020$

Journal of Economics, Business and Administration (JEBA) - E-ISSN: 2746-1688 13 
community. This is indicated by the existence of various public complaints regarding service discrimination.

Good service is a person's ability to provide services that can provide satisfaction to customers with a specified standard, [4]. The indicator for the quality of public services can be seen from 5 dimensions, including, [18]:

1. Tangibles: Service quality such as physical office facilities, computerization, administration, waiting rooms, and information places.

2. Reliability: Ability and reliability to provide reliable service.

3. Responsiveness: The ability to assist and provide services quickly and accurately while being responsive to the wishes of the community.

4. Assurance: Ability and friendliness and courtesy of employees in ensuring public trust.

5. Empathy: A firm yet attentive attitude from employees to society.

In Boalemo Regency, there are 7 districts, and there are several villages that cannot be reached by Singnal Digital, namely Wonosari and Paguyaman Pantai District, some of which are still experiencing difficulties in accessing the internet. Therefore, not all of the people in the management of population documents are well served and also still require high costs in their management even though the process of managing population administrative documents is free.

In its realization, the issuance of Identity Cards (KTP) and other civil registration documents is often different from what is stated in the Standard Operating Procedures (SOP) and as a result of the above it must be admitted that it will gradually reduce the level of public confidence in the ability and performance of the government, and there are still some employees who show their behavior that is not friendly and polite to the community when asked for information about administrative procedures and completeness, which are often unfriendly, thus giving a lack of empathy in community services as service users at the Population and Civil Registration Office of Boalemo Regency, as well as the lack of support for facilities and infrastructure such as waiting rooms, number of chairs, desks for writing, toilets, prayer rooms, complaint boxes, room temperature, cargo printers, generators, UPS and servers.

Regarding the quality of public services, according to the researchers' assumption, it is influenced by leadership behavior and employee work motivation. Leadership behavior is an individual's response as a motivator in an organization to an action that can be observed and has a positive or negative impact on an organization.

Leadership is an important factor in providing direction to employees, especially in these times when everything is completely open, so the leadership needed is leadership that can empower employees.

Leadership that can foster employee work motivation is leadership that can foster employee confidence along their respective duties. Besides, motivation can also make a significant contribution to improving service quality.

\section{Science of Public Administration}

Administration as the entire process of work between two or more human beings based on a certain rationality in order to achieve a predetermined goal [9]. There are several things contained in the definition, among others:

1. Administration as art is a process known only the beginning is finally unknown,

2. Administration has certain elements, namely the existence of two or more people, the existence of objectives to be achieved, the existence of tasks or tasks that must be carried out, the existence of equipment and equipment to carry out those tasks into the group of equipment 
and equipment including time, place, material equipment and other means,

3. That the administration as a process of cooperation is not a new thing because it has arisen together with the emergence of human civilization. Strictly, administration as an art is a social phenomenon.

Administration in a narrow sense is the preparation and systematic recording and information with the intention to provide information and facilitate the obtaining of it in its entirety and in relationships with each other. The data and information in question relate to organizational activities, either for internal or external purposes. While the administration in a broad sense is a cooperation activity carried out by a group of people based on the division of work as determined in the structure by utilizing resources to achieve goals effectively and efficiently [7].

Administration in a broad sense can be reviewed from 3 (three) points of view of understanding, namely the angle: process, function, and pranataan (instutision). Reviewed from the point of view of the process, administration is the whole process that starts from the process of thought, planning, arrangement, mobilization / guidance, supervision to the process of achieving goals. To achieve a goal, one must think first, then set / determine how to achieve that goal and then achieve it themselves until the desired goal. All of these activities are summarized in an administrative sense.

Viewed from the point of view of a function or task, administration means that the whole action (activity) that inevitably has to be done consciously by a person or organizational group of people who are domiciled as "administrators" or who occupy the top management of an organization. Reviewed from the point of administration is defined as an institution such as PN Housing Development (now PT Pembangunan perumahan [5].
Public administration is the process of cooperation between two or more people in carrying out government duties to achieve the government's goals that have been set. Broadly speaking, the scope of public administration is the topics discussed from the development of public administration science. Some opinions on the scope of public administration. namely:

1. Bureaucratic and organizational behavior has relationships within public organizations.

2. The regulation of human resources, state assets, market behavior that is the community is called public management.

3. Do something or not that has been approved by the public or yourself called implementation [6].

State administration or public administration is a variety of management activities carried out by the government (executive) starting from planning, organizing, implementing and supervising development programs by involving the legislature, the judiciary and the community in order to achieve the government's vision and mission [14].

\section{Management}

Etymologically, the word management comes from The English language, namely management, which is developed from the word to manage, which means to manage or manage. The word manage itself comes from the Italian, maneggio, which is adopted from latin managiare, which comes from the word manus, which means hand.

In terminology there are many definitions put forward by many experts [15]. Management is a typical process consisting of planning, organizing, mobilizing and controlling actions carried out to achieve the goals that have been set through the utilization of human resources and other resources [3].

Management can be defined as working with people to determine, interpret and 
achieve organizational objectives by implementing the functions of planning, organizing, personnel preparation or staffing, direction and leadership (leading), and controlling [2]. Management is the process of planning, organizing, directing and supervising the efforts of members and the use of other organizational resources in order to achieve the organization's goals that have been set. From the above definitions, it can be concluded that management is a series of activities to plan, organize, mobilize, control and develop all efforts in managing and utilizing human resources, facilities and infrastructure to achieve organizational goals that have been set effectively and efficiently.

\section{Public Service Quality Concept}

Quality is basically a word that bears relative meaning because it is abstract, quality can be used to assess or determine the level of adjustment of a thing to its requirements or specifications. Quality is:

1. Continuity or improvement,

2. Usage match,

3. Improvement or improvement of sustainability,

4. Free from damage,

5. Something that can make customers happy [16].

Quality has many different and varied definitions, ranging from conventional to more strategic. Conventional definitions of quality usually describe the characteristics of a product such as performance, reliability, easy ofilouse, aesthetics (esthetic), and similar [8]. Whereas in strat-egis definition that quality is everything that is able to meet the wants and needs of customers (meeting the needs of costumers).

Quality is a word that bears a relative meaning because it is abstract, quality can also be used to assess or determine the level of adjustment of a thing to the retirement-tan or specifications. If the requirements or specifications are met means the quality of a thing in question can be said well, on the contrary if the retirement is not met then it is said to be not good [6].

\section{RESEARCH METHOD}

This research uses a quantitative approach. It was conducted to explain the influence between variables, determine the causality of the variables, test the theory, and look for generalizations that have predictive value (to predict a symptom).

Quantitative is research of numbers and analysis using statistics. The use of this method is used following the aims and objectives of the research, namely to determine how much influence the independent variable has on the dependent variable to be studied [11].

\section{Operational Definition of Variables}

1. Quality of Service Instruments

In this research, the indicators used consisted of reliability, responsiveness, assurance, empathy, and tangibles. Measurement of Quality of service in this research used a Likert scale with a score of 5 for always, 4 for often, 3 for rarely, 2 for occasional answers, and 1 for never.

2. Leadership Behavior Instruments

Leadership behavior is a pattern of behavior shown by that person when influencing the activities of others. The indicators include the ability to foster good cooperation and relationships, effective ability, participatory leadership, time-sharing, and delegate tasks or authority which is reflected in the scores obtained by respondents when answering leadership behavior instruments. Measurement of leadership behavior in this research uses a Likert scale with a score of 5 for always, a score of 4 for often, a score of 3 for rarely answers, a score of 2 for answers sometimes, and a score of 1 for answers never.

3. Work Motivation Instruments

Motivation is a process of encouragement that arises from within and outside the individual that takes place 
consciously in carrying out an activity to achieve certain goals. And the indicators include:
a. Motivation to work,
b. Progress in a career,
c. Recognition obtained,
d. Responsibility at work,
e. Interest in tasks,
f. encouragement to achieve.

\section{Primary Data Sources}

Primary data is data obtained from respondents directly from the source. Data sourced from all respondent employees at the Population and Civil Registration office of Boalemo Regency. Primary data is obtained from a field survey using a questionnaire.

\section{Secondary Data Sources}

Secondary data is data obtained from records, books, magazines, previous research, indirectly from the source. Data comes from the Population and Civil Registration office of Boalemo Regency where the data revolves around the situation and condition of the Population and Civil Registration Office of Boalemo Regency.

\section{Population and Sample}

The population is the entire amount consisting of objects or sources that have certain characteristics and qualities that are determined by the researcher for research and then draw conclusions, [13]

The population in this research were all employees at the Population and Civil Registration Office of Boalemo Regency, as many as 34 people. The sample is part of the total of characteristics possessed by the population, [10]. Because the total population is less than 100 respondents, the sample selection method used is a census, that is, questionnaires are distributed to all populations, namely 34 respondents or total/saturated samples.

\section{Data Collection Technique}

To obtain the data needed to analyze hypothesis testing, a survey method is used by collecting data through Observation, Questionnaire, and Documentation.

\section{Validity and Reliability Test}

1. Validity Test

The validation test is used to determine whether a questionnaire is valid, a questionnaire is declared valid if the questions on the questionnaire can reveal something that will be measured by the questionnaire.

2. Reliability Test

Reliability is an index that shows the extent to which a measuring instrument can be trusted or reliable. To find out whether the measuring instrument is reliable or not tested by the Cronbach Alpha method. If the Alpha coefficient shows $>0.6$, it can be said that the items in the questionnaire are reliable [1].

\section{Data Analysis Technique}

1. Descriptive Statistical Analysis

The use of this analysis aims to describe the characteristics of the respondents studied by distributional of items from each variable. The descriptive size is the assignment of numbers, both in the number of respondents and in percentage figures.

2. Inferential Statistical Analysis

The inferential statistical technique used is path analysis, which is the development of multiple regression analysis that describes the magnitude of the influence of the independent variables on the related variables indirectly. This analysis consists of:

a. Classic assumption test

Before the data is analyzed further using multiple regression analysis, first a classic assumption test is carried out which consists of:
1. Normality Test
2. Multicollinearity Test
3. Heteroscedasticity Test

b. Hypothesis testing

The next test that must be done is hypothesis testing. This hypothesis 
test aims to determine the relationship between the dependent variable and the independent variable. The tests carried out are as follows:

1. Partial t-test

2. Simultaneous f test

\section{RESEARCH RESULT}

Table 1. Validity of leadership behavior

\begin{tabular}{cccc}
\hline $\begin{array}{c}\text { State- } \\
\text { ment }\end{array}$ & $\mathrm{R}_{\text {count }}$ & $\mathrm{R}_{\text {table }}$ & Ket \\
\hline 1 & 0.7120 & 0.3390 & Valid \\
\hline 2 & 0.8230 & 0.3390 & Valid \\
\hline 3 & 0.9200 & 0.3390 & Valid \\
\hline 4 & 0.9310 & 0.3390 & Valid \\
\hline 5 & 0.8850 & 0.3390 & Valid \\
\hline 6 & 0.8370 & 0.3390 & Valid \\
\hline 7 & 0.8400 & 0.3390 & Valid \\
\hline 8 & 0.8870 & 0.3390 & Valid \\
\hline 9 & 0.7870 & 0.3390 & Valid \\
\hline 10 & 0.8970 & 0.3390 & Valid \\
\hline
\end{tabular}

Table 2. Validity of Work Motivation

\begin{tabular}{cccc}
\hline Statement & $\mathrm{R}_{\text {table }}$ & $\mathrm{R}_{\text {count }}$ & Ket \\
\hline 1 & 0.6300 & 0.3390 & Valid \\
\hline 2 & 0.6720 & 0.3390 & Valid \\
\hline 3 & 0.7290 & 0.3390 & Valid \\
\hline 4 & 0.6650 & 0.3390 & Valid \\
\hline 5 & 0.7750 & 0.3390 & Valid \\
\hline 6 & 0.6380 & 0.3390 & Valid \\
\hline 7 & 0.5900 & 0.3390 & Valid \\
\hline 8 & 0.7720 & 0.3390 & Valid \\
\hline 9 & 0.6920 & 0.3390 & Valid \\
\hline 10 & 0.6620 & 0.3390 & Valid \\
\hline
\end{tabular}

Table 3. Validity of Service Quality

\begin{tabular}{cccc}
\hline Statement & $\mathrm{R}_{\text {count }}$ & $\mathrm{R}_{\text {table }}$ & Ket \\
\hline 1 & 0.6040 & 0.3390 & Valid \\
\hline 2 & 0.4980 & 0.3390 & Valid \\
\hline 3 & 0.8470 & 0.3390 & Valid \\
\hline 4 & 0.8080 & 0.3390 & Valid \\
\hline 5 & 0.9120 & 0.3390 & Valid \\
\hline 6 & 0.8070 & 0.3390 & Valid \\
\hline 7 & 0.8350 & 0.3390 & Valid \\
\hline 8 & 0.8160 & 0.3390 & Valid \\
\hline 9 & 0.8860 & 0.3390 & Valid \\
\hline & & &
\end{tabular}

\begin{tabular}{llll}
\hline 10 & 0.8400 & 0.3390 & Valid \\
\hline
\end{tabular}

\section{Reliability Testing}

1. Leadership Behavior Variable

Based on the results of the analysis using the Alpha Croncbach technique, the reliability coefficient value of the leadership behavior variable was 0.820 , which was greater than the predetermined standard value of 0.6. This shows that the instruments in this research are reliable or trustworthy and can be used for further research.

2. Work Motivation Variable

Based on the results of the analysis using the Alpha Croncbach technique, the reliability coefficient value of the work motivation variable was 0.848 which was greater than the predetermined standard value of 0.6. This shows that the instruments in this research are reliable or trustworthy and can be used for further research.

3. Service Quality Variable

Based on the results of the analysis using the Alpha Croncbach technique, the reliability coefficient value of the service quality variable is 0.830 which is greater than the predetermined standard value of 0.6. This shows that the instruments in this research are reliable or trustworthy and can be used for further research.

\section{Multiple Regression Analysis}

$$
\hat{\mathrm{Y}}=7.914+0,363 \mathrm{X} 1+0,464 \mathrm{X} 2+\varepsilon
$$

Based on the regression equation model, the following things can be interpreted:

1. A constant value of 7,914 is a fixed value of the Service Quality variable at the Population and Civil Registration Office of Boalemo Regency if there is no influence on leadership behavior and work motivation.

2. The regression coefficient value of the $\mathrm{X} 1$ variable (leadership behavior) is 0.363 , indicating that every change in the competency variable of 1 unit will 
affect office quality by 0.363 times the unit.

3. The regression coefficient value of the $\mathrm{X} 2$ variable (work motivation) is 0.464 , indicating that every change in the work motivation variable of 1 unit will affect the quality of service in the office by 0.464 times the unit.

The regression coefficient value of the $\mathrm{X} 3$ variable (Work Motivation) is 0.155 , indicating the regression coefficient value in the direction of pa. positive shows that there is a positive impact on leadership behavior and work motivation.

\section{t-Test (Parsial)}

\section{Leadership Behavior Variable}

Based on the t-test value obtained a Tukey value of 5.268, which has a significance value of leadership behavior $(0.000)$ which is smaller than the probability value of 0.05 . So, it can be concluded that leadership behavior has a significant effect on service quality in the Population and Civil Registration Office of Boalemo Regency, with the level of influence partially variable X1 on $\mathrm{Y}$ is $65 \%$.

2. Work Motivation Variable

Based on the t-test value, it is obtained a Tukey value of 7,428, which has a significant value of work motivation $(0,000)$ which is smaller than the probability value of 0.05 . So, it can be concluded that work motivation has a significant effect on service quality in the Population and Civil Registration Office of Boalemo Regency, with the level of influence partially variable $\mathrm{X} 2$ on $\mathrm{Y}$ is $43 \%$

\section{Simultaneous Test}

Based on the value of the F-test, it was obtained 18,466, the significance value of work motivation $(0,000)$ is smaller than the probability value of 0.05 . So, it can be concluded that leadership behavior and work motivation have a significant effect on service quality in the Population and Civil Registration Office of Boalemo Regency, with the level of influence simultaneously variable $\mathrm{X} 1$ and variable $\mathrm{X} 2$ on $\mathrm{Y}$ of $72 \%$. While the remaining $28 \%$ is influenced by other factors that are not included in the research variables.

\section{DISCUSSION \\ Effect (X1) on (Y)}

Public service is very important and becomes the main barometer to measure the success of a leader in mobilizing and directing all the potential that exists in the organization he leads. First, public services have been the domain where the state represented by the government interacts with non-governmental institutions. In this realm, there is a very intensive struggle between the government which is directly represented by the style or behavior of public leadership which is obliged to provide public services and its citizens.

The results showed that based on the $\mathrm{t}-$ test value obtained a Tukey value of 5.268 which has a significance value of leadership behavior (0.000) which is smaller than the probability value of 0.05 . So it can be concluded that leadership behavior has a significant effect on service quality in the Population and Civil Registration Office of Boalemo Regency. These results are also reinforced by the test of determination which shows that the partial level of influence of variable $\mathrm{X} 1$ on $\mathrm{Y}$ is $65 \%$.

Poor public service practices will make it easier for citizens and the community to evaluate the bad style or behavior of their leaders. Success in realizing prime and quality public services will have an impact on increasing public support and trust in the success of work programs which are the main goals of his leadership through public services. Second, the public services that the government must provide to the community, make leaders have to 
continuously motivate their subordinates who have direct contact with the community at all times.

The success of subordinates in providing quality service to the community is also the success of the leader, and vice versa. Third, the increasing public awareness in interacting with public organizations has made leaders have to be accountable, have high integrity and transparency, considering that in an atmosphere of reform everything can be seen quickly and completely open. Therefore, now the leadership needed is a leader who is responsible for his duties with high integrity and transparency.

Public service involves all aspects of life which are very broad. In-state life, the role of government has a function to provide various public services needed by the community. In the implementation of public services, the public bureaucracy is more power-oriented so that it makes the bureaucracy further away from its mission to provide services to the community, officials show more power than as public servants, the widespread practices of corruption, collusion, and nepotism in the public bureaucracy are increasingly tarnished public image of the public bureaucracy, these practices cause the bureaucracy to become distant from its people and make people no longer trust the bureaucracy.

\section{Effect (X2) on (Y)}

To be able to provide services to the community, employees always pay attention to the factors that encourage employees to work productively, one of which is paying attention to employee work motivation. By paying attention to the work motivation factor of employees, employees at work will always be accompanied by feelings of pleasure and are not forced and have high work morale. Motivation questions how to direct the power and potential of subordinates so that they are willing to work together productively, succeed in achieving and realizing predetermined goals.

Motivation is important because it is causes, channels, and supports human behavior so that they are willing to work hard and enthusiastically to achieve the desired results.

Motivation is a driving force that results in a member of the organization willing and willing to mobilize abilities in the form of expertise or personnel skills and time to carry out various activities that are their responsibility and fulfill their obligations to achieve predetermined organizational goals and objectives [12].

The results showed that based on the $\mathrm{t}-$ test value, the Tukey value was obtained at a value of 7,428 , which means that the significance value of work motivation $(0,000)$ is smaller than the probability value of 0.05 . Therefore, it can be concluded that work motivation has a significant effect on service quality in the Population and Civil Registration Office of Boalemo Regency. This result is also reinforced by the test of determination which shows that the partial level of influence of the $\mathrm{X} 2$ variable on $\mathrm{Y}$ is $43 \%$.

The existence of motivation becomes the force for a person or individual to do something and it can be achieved when one's needs can be fulfilled.

Work motivation is the provision of a force that creates a person's enthusiasm for work, so that, they are willing to work together, work effectively, and are integrated with all their efforts to achieve satisfaction [3]. An important driving factor that causes humans to work is a need that must be met. Work motivation is the various efforts made by humans to fulfill their wants and needs. However, so that his wants and needs can be fulfilled is not easy to get without maximum effort. In fulfilling their needs, someone will behave following one's encouragement and will behave following the urges they have and what underlies their behavior. 
Optimally humans are the main key to developing an organization so that the organization can run smoothly and efficiently. Human resources have different behavior. Human behavior reflects the way and their sincerity to work, where this will affect the success of achieving the goals of an organization. Employees are one of the resources that carry out activities in an organization. Either as an organizational planner maker or as an executor of the organization's activities. The achievement or failure of the goals of an organization that has been set depends on the employees in the organization. The Population and Civil Registration Office of Boalemo Regency is an office that is tasked with carrying out government functions in providing population administration services to the community.

The quality of service will have a direct impact on the progress or setbacks obtained from the agency or company.

Several factors influence service quality, for example, leadership, work motivation, and work environment, [17].

Based on the results of the study showed that the value of the F-test was 18,466 , which means that the significance value of work motivation $(0,000)$ is smaller than the probability value of 0.05 . So it can be concluded that leadership behavior and work motivation have a significant effect on service quality in the Population and Civil Registration Office of Boalemo Regency.

From the data obtained above, the role of a leader is very important to produce quality service. Because, in managing and controlling various functions in the organization to remain consistent with organizational goals, a leader who influences employee attitudes is needed, the effectiveness of a leader will be greatly influenced by the characteristics of his subordinates. Apart from coming from existing leadership, motivation is also very much needed by subordinates, both physiologically and psychologically because with these motivation employees can improve their performance. If employees are satisfied with what they receive, and also good leadership, their performance will also improve.

The results of this research are supported by previous research conducted by Sastra Tamami, 2016 with the title The Influence of Leadership Style and Motivation on Service Quality and Employee Performance in the DPRD secretariat of Batam City.

Based on the results of the research and analysis carried out, it can be concluded from the results of the regression analysis with the two-way equation showing that the combined influence of leadership style and motivation variables is strong on the employee work service variable with a value of $54.8 \%$, with a significant number of $0.000<0.05$. it can be said that the two independent variables have a significant (real) effect on employee work services. Partially or individually, the independent variable that most influences employee work services are a fair and proper motivation variable of 0.339 or $33.9 \%$ (the effect is quite strong).

\section{CONCLUSION}

Based on the analysis and the results of hypothesis testing in this research, it can be concluded that as follows:

1. There is a positive and significant influence between leadership behavior on service quality in the Population and Civil Registration of Boalemo Regency, which means that the better the behavior of a leader, the better the quality of service.

2. There is a positive and significant influence between work motivation on service quality in the Population and Civil Registration Office of Boalemo Regency, which means that the increase in employee motivation, the better the services provided. 
The Influence of Leadership Behaviour and Work Motivation on Service Quality at the Population and Civil Registration Office of Boalemo Regency

3. There is a positive and significant influence between leadership behavior and work motivation on service quality in the Population and Civil Registration Office of Boalemo Regency, which means that the increase in employee work motivation, the better the service provided.

\section{REFERENCE}

[1] Gujarati, Damodar. 2003. Ekonometrika Dasar. Terjemah Sumarno Zein. Jakarta: Erlangga.

[2] Hasibuan, Malayu S.P. 2016. Manajemen Sumber Daya Manusia. Edisi.Revisi. Jakarta: Penerbit PT Bumi Aksara.

[3] Kasmir. 2005. Etika Customer Service. RajaGrafindo Persada. Jakarta.

[4] Sugiyono. (2016). Metode Penelitian Kuantitatif, Kualitatif dan R\&D. Bandung: PT Alfabet.

[5] Sugiyono (2015). Metode Penelitian Kombinasi (Mix Methods). Bandung: Alfabeta.
[6] Siagian, Sondang P. 2003. Teori \& praktek kepemimpinan. Jakarta: Rineka Cipta.

[7] Sudarsono, S. S., Kamase, J., Ella, H., Rachman, A., \& Dunggio, T. (2020). Big data and content marketing on purchase decisions online in Indonesia. IOSR Journal Of Business And Management (IOSR-JBM), 22(2), 4246.

[8] Sujarweni, V. Wiratna. 2014. Metode Penelitian: Lengkap, Praktis, dan Mudah Dipahami. Yogyakarta: Pustaka Baru Press.

[9] Tahir, A. (2014). Kebijakan publik dan transparansi penyelenggaraan pemerintahan daerah. Penerbit Alfabeta.

[10] Wibowo. (2007). Manajemen Kinerja. Edisi ketiga. Jakarta: PT.Raja Grafindo Prasada.

[11]Zeithaml, Valirie A., \&, Mary Jo. (2003). Service Marketing Integrating Customer Focus Across the Firm. New York: McGraw-Hill Companies 